\title{
Coordinatively and Electronically Unsaturated Tetraruthenium Clusters: Reversible Triple CO Addition to $\mathrm{Ru}_{4}(\mathrm{CO})_{9}\left(\mu-\mathrm{PPh}_{2}\right)\left[\mu_{4}-\mathrm{Ph} \mathrm{h}_{2} \mathrm{PCC}(\mathrm{Ph}) \mathrm{CC}(\mathrm{Ph})\right]$
}

\author{
Esther Delgado, ${ }^{\dagger, \ddagger}$ Y un Chi, ${ }^{\dagger, \S}$ Weibin Wang, ${ }^{\dagger}$ Graeme Hogarth, ${ }^{\dagger, l}$ Paul J . Low, ${ }^{\dagger}$ \\ Gary D. Enright, ${ }^{\dagger}$ Shie-Ming Peng,$^{\perp}$ Gene-Hsiang Lee,$^{\perp}$ and Arthur J . Carty*,+,\# \\ Steacie Institute for Molecular Sciences, National Research Council of Canada, \\ 100 Sussex Drive, Ottawa, Ontario, Canada K1A 0R6, Ottawa-Carleton Research Institute, \\ Department of Chemistry, University of Ottawa, 1125 Colonel By Drive, Ottawa, \\ Ontario, Canada K1S 5B6, Departamento de Quimica Inorgánica, Universidad Autónoma de \\ Madrid, 28049 Madrid, Spain, Department of Chemistry, University College London, \\ 20 Gordon Street, London WC1H OAJ , England, Department of Chemistry, \\ National Tsing Hua University, Hsinchu 30043, Taiwan, and Department of Chemistry, \\ National Taiwan University, Taipei 10764, Taiwan
}

Received March 9, 1998

Summary: Two electronically unsaturated tetraruthenium clusters, $\mathrm{Ru}_{4}(\mathrm{CO})_{9}\left(u-\mathrm{PPh}_{2}\right)\left[u_{4}-\mathrm{Ph}{ }_{2} \mathrm{PCC}(\mathrm{Ph}) \mathrm{CC}(\mathrm{Ph})\right]$ (2) and $\mathrm{Ru}_{4}(\mathrm{CO})_{10}\left(\mu-\mathrm{PPh}_{2}\right)\left[\mu_{4}-\mathrm{Ph}_{2} \mathrm{PC}(\mathrm{Ph}) \mathrm{CCC}(\mathrm{Ph})\right]$ (3), with spiked-triangular and open-chain structures have been synthesized via head-to-tail and head-to-head coupling of binuclear acetylides: cluster $\mathbf{2}$ contains a coordinatively unsaturated metal center and undergoes a fully reversible triple addition of carbon monoxide to afford $\mathrm{Ru}_{4}(\mathrm{CO})_{11}\left(\mu-\mathrm{PPh}_{2}\right)\left[\mu_{4}-\mathrm{Ph}_{2} \mathrm{PC}(\mathrm{O}) \mathrm{CC}(\mathrm{Ph}) \mathrm{CC}(\mathrm{Ph})\right]$ (4).

With the exception of molecules containing metals such as platinum and rhodium, which often favor a 16electron configuration in polymetallic compounds, coordinatively and electronically unsaturated clusters of the later transition metals are still relatively rare. ${ }^{1}$ This is particularly true for the iron triad. The few examples include $\mathrm{H}_{2} \mathrm{Os}_{3}(\mathrm{CO})_{10}$, which has a hydride-bridged $\mathrm{Os}=$ Os bond, ${ }^{2} \mathrm{HRu}_{3}(\mathrm{CO})_{9}\left(\mu-\mathrm{PPh}_{2}\right)$, where el ectronic unsaturation at a 16-electron metal site is partially compensated by a weak intramolecular interaction with a $\mathrm{P}-\mathrm{C}(\mathrm{Ph})$ bond ${ }^{3 \mathrm{a}}$ and $44-e$ ectron $\left[\mathrm{Ru}_{3} \mathrm{H}_{2}(\mathrm{CO})_{6}\left(\mathrm{PCy}_{3}\right)_{3}\right]^{3 \mathrm{~b}}$ For these clusters, unsaturation leads to an extensive addition and small molecule activation chemistry. We describe herein two new electronically unsaturated clusters, $\mathrm{Ru}_{4}(\mathrm{CO})_{9}\left(u-\mathrm{PPh}_{2}\right)\left[\mu_{4}-\mathrm{Ph}_{2} \mathrm{PCC}(\mathrm{Ph}) \mathrm{CC}(\mathrm{Ph})\right]$ (2) and $\mathrm{Ru}_{4}(\mathrm{CO})_{10}\left(u-\mathrm{PPh}_{2}\right)\left[\mu_{4}-\mathrm{Ph}_{2} \mathrm{PC}(\mathrm{Ph}) \mathrm{CCC}(\mathrm{Ph})\right]$ (3), with spiked-triangular and open-chain $\mathrm{Ru}_{4}$ frameworks, re-

\footnotetext{
* To whom correspondence should be addressed at the National Research Council of Canada.

+ National Research Council of Canada.

¥ Universidad Autónoma de Madrid.

$\S$ National Tsing Hua University.

"University College London.

$\perp$ National Taiwan University.

\#University of Ottawa.

(1) (a) Mingos, D. M. P.; Wales, D. J . Introduction to Cluster Chemistry; Prentice Hall, Englewood Cliffs, NJ , 1990. (b) The Chemistry of Metal Cluster Complexes; Shriver, D. F., Kaesz, H. D., Adams, R. D., Eds.; VCH: New York, 1990. (c) Vargas, M. D.; Nicholls, J . N. Adv. Inorg. Chem. Radiochem. 1986, 30, 123.

(2) (a) Knox, S. A. R.; Koepke, J. W.; Andrews, M. A.; Kaesz, H. D. J. Am. Chem. Soc. 1975, 97, 3942. (b) Orpen, A. G.; Rivera, A. V.; Bryan, E. G.; Pippard, D.; Sheldrick, G. M. J . Chem. Soc., Dalton Trans. 1978, 723.

(3) (a) MacLaughlin, S. A.; Taylor, N.J .; Carty, A. J . Can. J . Chem. 1982, 60, 87. (b) Suss-Fink, G.; Godefroy, I.; Ferrand, V.; Neels, A.; Stoeckli-Evans, H. J . Chem. Soc., Dalton Trans. 1998, 515.
}

spectively. In $\mathbf{2}$ unsaturation is local ized at a single 16e ruthenium site, whereas $\mathbf{3}$ is a 64 e cluster with only three $\mathrm{Ru}-\mathrm{Ru}$ interactions, one of which is a short Ru$\mathrm{Ru}$ bond. Cluster $\mathbf{2}$ undergoes a remarkable, unprecedented, and fully reversible triple addition of $\mathrm{CO}$ to afford $\mathrm{Ru}_{4}(\mathrm{CO})_{11}\left(\mu-\mathrm{PPh}_{2}\right)\left[\mu_{4}-\mathrm{Ph}_{2} \mathrm{PC}(\mathrm{O}) \mathrm{CC}(\mathrm{Ph}) \mathrm{CC}(\mathrm{Ph})\right]$ (4).

An emerging strategy for the synthesis of polymetallic polycarbon ligand arrays is the intermolecular coupling of ynyl or polyynyl ligands coordinated in a multisite fashion on bi- or trinuclear frameworks. ${ }^{4}$ We have applied this methodology to the condensation of $\mathrm{Ru}_{2^{-}}$ $(\mathrm{CO})_{6}\left(\mu-\mathrm{PPh}_{2}\right)\left(\mu-\eta^{1}: \eta^{2}-\mathrm{C} \equiv \mathrm{CPh}\right)$ (1). Refluxing a toluene solution of $\mathbf{1}$, and fractional crystallization from $\mathrm{CH}_{2-}$ $\mathrm{Cl}_{2} / \mathrm{CH}_{3} \mathrm{OH}$ gave orange $\mathrm{Ru}_{4}(\mathrm{CO})_{9}\left(\mu-\mathrm{PPh}_{2}\right)\left[\mu_{4}-\mathrm{Ph}_{2} \mathrm{PCC}-\right.$ $(\mathrm{Ph}) \mathrm{CC}(\mathrm{Ph})](2 ; 68 \%)$ and brown $\mathrm{Ru}_{4}(\mathrm{CO})_{10}\left(\mu-\mathrm{PPh}_{2}\right)\left[\mu_{4}-\right.$ $\left.\mathrm{Ph}_{2} \mathrm{PC}(\mathrm{Ph}) \mathrm{CCC}(\mathrm{Ph})\right](3 ; 19 \%)$ (Scheme 1). Spectroscopic data ${ }^{5}$ established the presence of phosphido and phosphine ligands, but X-ray analysis ${ }^{6}$ was needed to determine the nature of the coupled organic fragments.

The structure of $\mathbf{2}$ (Figure 1 ) has three principal features. A spiked-triangular (4 Ru-Ru) $\mathrm{Ru}_{4}$ framework has metal - metal bond lengths in the range 2.677(2) $(\mathrm{Ru}(3)-\mathrm{Ru}(4))$ to 3.015(1) $\AA(\mathrm{Ru}(2)-\mathrm{Ru}(3)) . \mathrm{A} \mathrm{PC}_{4}$ chain is bound to all four metal atoms, formed by headto-tail coupling of two ynyl ligands and $\mathrm{P}-\mathrm{C}$ bond formation between a phosphido bridge and $\mathrm{C}_{\alpha}$ of one

(4) (a) Carty, A. J .; Hogarth, G.; Enright, G. D.; Frapper, G. J . Chem. Soc., Chem. Commun. 1997, 1883. (b) Davies, J. E.; Mays, M. J . Raithby, P. R.; Sarveswaran, K. Angew. Chem., Int. Ed. Engl., 1997 36, 2668. (c) Chi, Y.; Carty, A. J .; Blenkiron, P.; Delgado, E.; Enright G. D.; Wang, W.; Peng, S.-M.; Lee, G.-H. Organometallics 1996, 15, 5269.

(5) Selected spectral data for 2: MS (FAB, $\left.{ }^{102} \mathrm{Ru}\right) \mathrm{m} / \mathrm{z} 1232\left(\mathrm{M}^{+}\right)$; IR $\left(\mathrm{C}_{6} \mathrm{H}_{14}\right) v(\mathrm{CO}) 2061$ (s), 2034 (m), 2028 (w), 2000 (vs), 1997 (s), 1983 (m), $1974(\mathrm{vw}), 1963(\mathrm{~m}), 1930(\mathrm{vw}, \mathrm{br}) \mathrm{cm}^{-1}$; ${ }^{1} \mathrm{H}$ NMR $\left(600 \mathrm{MHz}_{\text {, }}\right.$ $\left.\mathrm{CDCl}_{3}\right) \delta 8.24\left(\mathrm{dd}, 2 \mathrm{H}, \mathrm{J}_{\mathrm{H}-\mathrm{H}}=7.2 \mathrm{~Hz}\right.$ and $\left.\mathrm{J}_{\mathrm{P}-\mathrm{H}}=8.7 \mathrm{~Hz}\right), 7.69(\mathrm{t}, 1 \mathrm{H}$, $\mathrm{H}-\mathrm{H}=7.2 \mathrm{~Hz}), 7.59(\mathrm{t}, 2 \mathrm{H}, \mathrm{J} \mathrm{H}-\mathrm{H}=7.2 \mathrm{~Hz}), 7.28(\mathrm{~m}, 5 \mathrm{H}), 7.22-7.14$ $(\mathrm{m}, 5 \mathrm{H}), 7.04-6.69(\mathrm{~m}, 9 \mathrm{H}), 6.80-6.77(\mathrm{~m}, 4 \mathrm{H}), 6.67\left(\mathrm{t}, 2 \mathrm{H}, \mathrm{J}_{\mathrm{H}-\mathrm{H}}=\right.$ $7.5 \mathrm{~Hz}) ;{ }^{31} \mathrm{P}\left\{{ }^{1} \mathrm{H}\right\} \mathrm{NMR}\left(121.5 \mathrm{MHz} \mathrm{CDCl}_{3}\right) \delta 155.5(\mathrm{~s}, 1 \mathrm{P}), 56.8(\mathrm{~s}, 1 \mathrm{P})$. Anal. Calcd for $\mathrm{C}_{49} \mathrm{H}_{30} \mathrm{O}_{9} \mathrm{P}_{2} \mathrm{Ru}_{4}$ : C, 47.89, $\mathrm{H}, 2.46$. Found: $\mathrm{C}, 47.88$ $H, 2.38$. Selected spectral data for 3: MS (FAB) m/z $1260\left(M^{+}\right)$. IR $\left(\mathrm{C}_{6} \mathrm{H}_{14}\right) v(\mathrm{CO}), 2079$ (s), 2045 (s), 2025 (m), 1990 (vs), 1966 (m), 1950

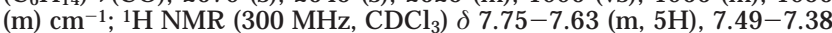
$(\mathrm{m}, 8 \mathrm{H}), 7.26-7.17(\mathrm{~m}, 7 \mathrm{H}), 7.15-7.03(\mathrm{~m}, 3 \mathrm{H}), 6.97(\mathrm{~m}, 3 \mathrm{H}), 6.90-$ $6.85(\mathrm{~m}, 4 \mathrm{H}) ;{ }^{31} \mathrm{P}\left\{{ }^{1} \mathrm{H}\right\}$ NMR $\left(121.5 \mathrm{MHz}, \mathrm{CDCl}_{3}\right): \delta 152.3(\mathrm{~s}, 1 \mathrm{P}), 56.8$ $(\mathrm{s}, \mathrm{P})$. Anal. Calcd for $\mathrm{C}_{50} \mathrm{H}_{30} \mathrm{O}_{10} \mathrm{P}_{2} \mathrm{Ru}_{4}$ : C, 47.77, $\mathrm{H}, 2.38$. Found: $\mathrm{C}$, 47.92, H, 2.20. 
Scheme 1
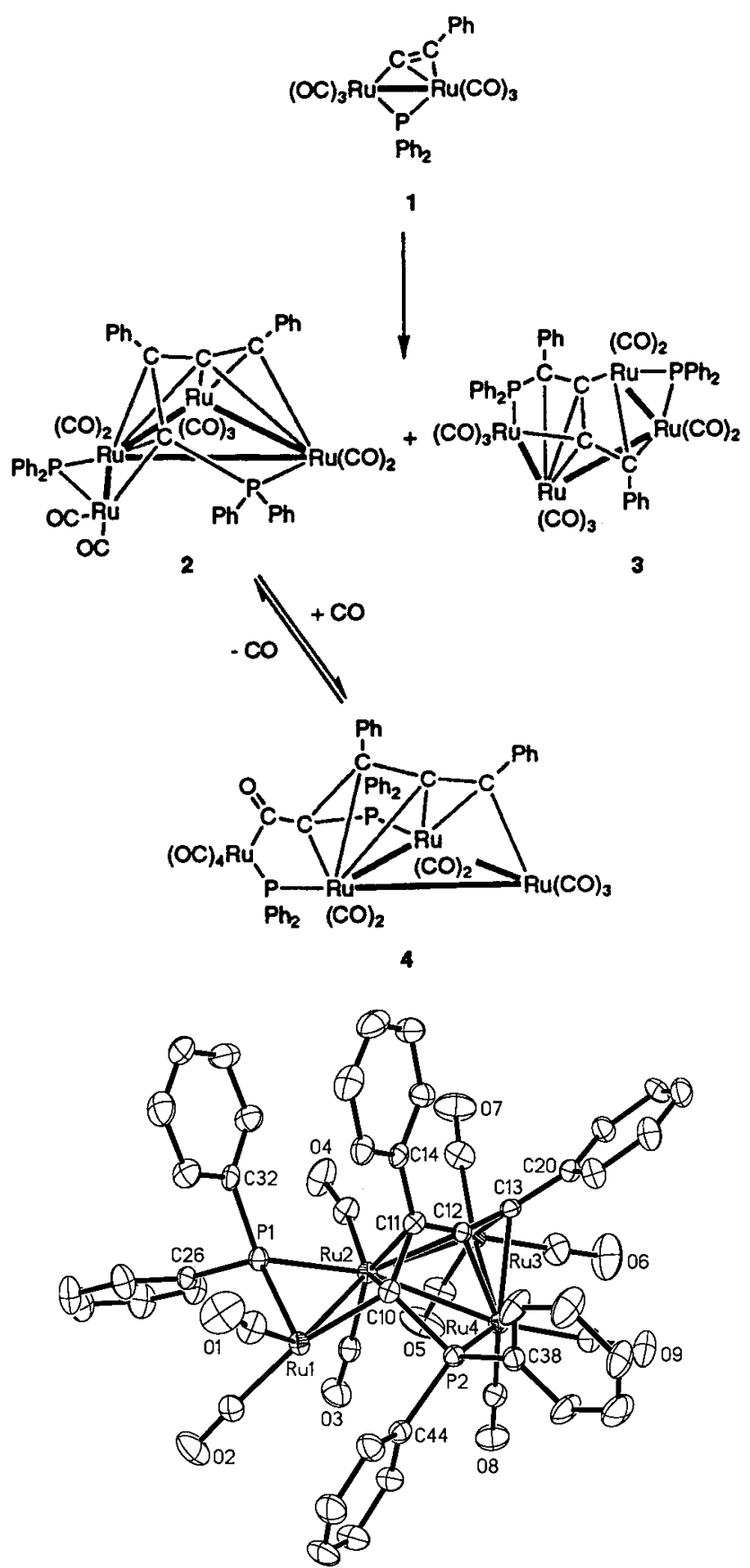

Figure 1. ORTEP plot of compound 2. Selected bond lengths $(\AA) \mathrm{Ru}(1)-\mathrm{Ru}(2), 2.920(1) ; \mathrm{Ru}(2)-\mathrm{Ru}(4), 2.8319$ (8); $\mathrm{Ru}(1)-\mathrm{C}(10), 2.021(6) ; \mathrm{Ru}(2)-\mathrm{C}(10), 2.274(5) ; \mathrm{Ru}(2)-$ $\mathrm{C}(11), 2.240(6) ; \mathrm{Ru}(2)-\mathrm{C}(12), 2.184(6) ; \mathrm{Ru}(3)-\mathrm{C}(13), 2.063-$ (6); $\mathrm{Ru}(4)-\mathrm{C}(12), 2.086(6) ; \mathrm{Ru}(4)-\mathrm{C}(13), 2.318(6) ; \mathrm{P}(2)-$ $C(10), 1.796(6) ; C(10)-C(11), 1.474(8) ; C(11)-C(12), 1.430(8) ;$ $\mathrm{C}(12)-\mathrm{C}(13), 1.362(8)$.

acetylide. The $\mathrm{Ph}_{2} \mathrm{PCC}(\mathrm{Ph}) \mathrm{CC}(\mathrm{Ph})$ chain functions as a $9 e$ donor to the cluster and can be considered as a diphenylphosphino substituted ene-yne. In other examples of ynyl-ynyl coupling reported recently, only head-to-head linkage was observed. ${ }^{4}$ The most unusual aspect of $\mathbf{2}$ is that the electron deficiency implied by its 62 e $(4 M-M)$ count is manifest in coordinative and el ectronic unsaturation at a single $16 \mathrm{e} \mathrm{Ru}(1)$ site. This metal atom is coordinated to two $\mathrm{CO}$ groups and a phosphido bridge and has a $\sigma$-bond to $\mathrm{C}(10)$ and a contact with $\mathrm{Ru}(2)(\mathrm{Ru}(1)-\mathrm{Ru}(2)=2.920(1) \AA)$. The

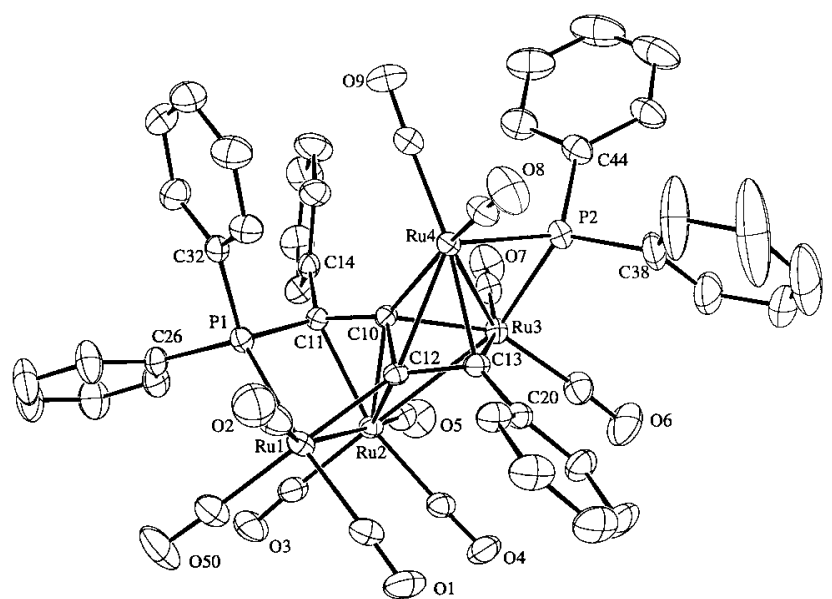

Figure 2. ORTEP plot of compound 3. Selected bond lengths ( $\AA$ ) not given in the text: $R u(1)-P(1), 2.366(2)$; Ru(2)-C(11), 2.215(4); $R u(3)-C(13), 2.204(4) ; R u(4)-C(12)$, 2.434(4); $R u(4)-C(13), 2.127(4) ; P(1)-C(11), 1.824(5)$.

ster eochemistry at $\mathrm{Ru}(1)$ is also highly unusual (Figure 1) with a vacant coordination position evident trans to $\mathrm{P}(1)$. The phenyl group $\mathrm{C}(44)-\mathrm{C}(49)$ partially protects this site but is not coordinated.

Cluster 3 (Figure 2) consists of a twisted chain of four ruthenium atoms with one short $(\mathrm{Ru}(3)-\mathrm{Ru}(4)=2.7459$ (6) $\AA$ ) and two normal (average $2.855 \AA$ ) bonds. This skeletal arrangement is rare for tetrametal clusters. ${ }^{7}$ The hydrocarbyl chain in $\mathbf{3}$ differs from that in $\mathbf{2}$ in that head-to-head ynyl coupling has occurred, generating a $C(10)-C(12)$ bond $(1.498(6) \AA)$, while $P-C$ coupling has placed a phosphino group geminal to a phenyl substituent on $\mathrm{C}(11)$. The mode of attachment of the $\mathrm{C}_{4}$ fragment $(\mathrm{C}(11)-\mathrm{C}(10)-\mathrm{C}(12)-\mathrm{C}(13))$ on the tetrametal framework poses an interesting challenge for conventional chemical bonding descriptions. The central carbon atoms $\mathrm{C}(10)$ and $\mathrm{C}(12)$ are pentacoordinate, each being attached to three metal atoms $(C(10)-R u(2)$, 2.233(4); C(10)-Ru(3), 2.115(4); C(10)-Ru(4), 2.208(5); $\mathrm{C}(12)-\mathrm{Ru}(1), 2.091(4) ; \mathrm{C}(12)-\mathrm{Ru}(2), 2.309(4) ; \mathrm{C}(12)-$ $\mathrm{Ru}(4)$ 2.434(4) $\AA$ ), to a $C(P h)$ group $(C(10)-C(11), 1.454$ -

(6) Crystal data for 2: $\mathrm{C}_{49} \mathrm{H}_{30} \mathrm{O}_{9} \mathrm{P}_{2} \mathrm{Ru}_{4}, \mathrm{M}_{\mathrm{r}}=1228.99$, monoclinic space group $P 2_{1} / c, a=20.391(5) \AA, b=12.858(2) \AA, c=20.053(8) \AA$ $\beta=118.95(4)^{\circ}, V=4600.6(2) \AA^{3}, Z=4, \rho_{\text {calc }}=1.744 \mathrm{~g} \mathrm{~cm}^{-3}, \mathrm{~F}(000)=$ 2387, $\lambda(\mathrm{Mo} \mathrm{K} \alpha)=0.71067 \AA, \mathrm{T}=298 \mathrm{~K}, \mu=13.869 \mathrm{~cm}^{-1}$. The structure was solved and refined on the basis of $5020(I \geq 2 \sigma(I))$ observed (8067 measured) reflections (Enraf-N onius CAD-4 diffractometer) with a crystal of dimensions $0.10 \times 0.15 \times 0.50 \mathrm{~mm}$. Final R and $R_{w}$ values were 0.035 and 0.034 . The NRCVAX computer program suite was used. ${ }^{12} \mathrm{~A}$ final difference map showed residual electron density in the range \pm 0.54 e $\AA^{-3}$. Crystal data for $3: \mathrm{C}_{50} \mathrm{H}_{30} \mathrm{O}_{10} \mathrm{P}_{2-}$ $\mathrm{Ru}_{4} .2 \mathrm{CH}_{2} \mathrm{Cl}_{2}, \mathrm{M}_{\mathrm{r}}=1422.83$, monoclinic, space group $\mathrm{P} 2_{1} / \mathrm{n}$, $\mathrm{a}=$ 12.8483(6) $\AA, b=25.2745(12) \AA, c=16.5144(7) \AA, \beta=93.16(1)^{\circ}, V=$ $5354.6(3) \AA^{3}, Z=4, \rho_{\text {calc }}=1.752 \mathrm{~g} \mathrm{~cm}^{-3}, F(000)=2745.9, \lambda($ MoK $\alpha)=$ $0.70930 \AA, T=298 \mathrm{~K}, \mu=1.36 \mathrm{~mm}^{-1}$. The structure was solved and refined on the basis of $6584(\mathrm{I} \geq 2.5 \sigma(\mathrm{I}))$ observed reflections ( 21237 measured) (Siemens SMART CCD diffractometer) on a crystal of dimensions $0.10 \times 0.10 \times 0.10 \mathrm{~mm}$. Final $R$ and $R_{w}$ values were 0.032 and 0.036. A final difference map showed residual electron density from -0.63 to +0.95 e $\AA^{-3}$

(7) (a) Pomeroy, R. K. In Comprehensive Organometallic Chemistry II; Abel, E. W., Stone, F. G. A., Wilkinson, G., Eds.; Elsevier: Exeter, U.K., 1995. (b) Sappa, E.; Tiripicchio, A.; Toogood, G. E.; Carty, A. J . Prog. Inorg. Chem. 1987, 35, 407. (c) Keisper, J.: Polm, L. H.; van Koten, G.; Vrieze, K.; Nielsen, E.; Stam, C. H. Organometallics 1985, 4, 2006. (d) Polm, L. H.; Mul, W. P.; Elsevier,C. J .; Vrieze, K.; Christopherson, M. J . N.; Stam, C. H. Organometallics 1988, 7, 423. (e) Mul, W. P.; Elsevier, C. J .; van Leijen, M.; Spaans, J . Organome tallics 1991, 10, 251. (f) Bruce, M. I.; Hinchliffe, J. R.; Surynt, R. Skelton, B. W.; White, A. H. J . Organomet. Chem. 1994, 469, 89. (g) Low, P.J .; Enright, G. D.; Carty, A.J . J . Organomet. Chem., in press. 
(6); $C(12)-C(13), 1.438(6) \AA)$, and to each other via a long $C(10)-C(12)$ bond $(1.498(6) \AA)$. In the square cluster $\mathrm{Fe}_{4}(\mathrm{CO})_{8}\left(u-\mathrm{PPh}_{2}\right)_{2}\left(\mu_{4}-\mathrm{C}_{2} \mathrm{Ph}\right)_{2}$ a similar but even longer $\mathrm{C}-\mathrm{C}$ bonding interaction "through the cluster" resulted from $\mathrm{C}_{\alpha}-\mathrm{C}_{\alpha}$ acetylide coupling. ${ }^{4 a}$ Clearly for 3, $\mathrm{C}_{4}-\mathrm{Ru}_{4}$ bonding is multicentered, but the ligand can be simplistically described as a 9e donor, as represented by $\mathbf{A}$. Cluster $\mathbf{3}$ has 64 cluster valence electrons and

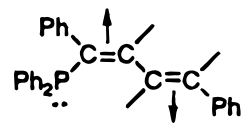

A

would be electron precise with a $66 \mathrm{e}(3 \mathrm{M}-\mathrm{M})$ count. However, in contrast to $\mathbf{2}$, its formal el ectron deficiency is not localized at one metal site.

Preliminary exploration of the chemical reactivity of coordinatively unsaturated 2 revealed novel and unexpected results. Bubbling $\mathrm{CO}$ through a $\mathrm{CDCl}_{3}$ solution of $\mathbf{2}$ for 10 min resulted in the clean and quantitative disappearance of ${ }^{31} \mathrm{P}$ resonances at 155.5 and $56.8 \mathrm{ppm}$ due to $\mu-\mathrm{PPh}_{2}$ and phosphine ligands of $\mathbf{2}$ and the concomitant growth of new peaks at 46.9 and $26.7 \mathrm{ppm}$ from the new cluster 4. $^{8}$ This facile carbonylation is fully reversible, the conversion back to $\mathbf{2}$ being rapid in air or under a stream of dinitrogen (Scheme 1). The cycle of CO addition and loss can be repeated many times with no noticeable decomposition. In the solid state this process is somewhat slower.

Crystals of $\mathbf{4}$ grown from $\mathrm{CH}_{2} \mathrm{Cl}_{2} / \mathrm{CH}_{3} \mathrm{OH}$ saturated with $\mathrm{CO}$ were subjected to X-ray analysis. ${ }^{8}$ As revealed in Figure 3, $\mathbf{4}$ is the tris- $\mathrm{CO}$ adduct of $\mathbf{2}$, namely $\mathrm{Ru}_{4}(\mathrm{CO})_{11}\left(u-\mathrm{PPh}_{2}\right)\left[u_{4}-\mathrm{Ph}_{2} \mathrm{PC}(\mathrm{O}) \mathrm{CC}(\mathrm{Ph}) \mathrm{CC}(\mathrm{Ph})\right]$. The CO addition is centered on the unsaturated pendant ruthenium center (Ru(1) in 2), which now carries four carbonyl ligands in $\mathbf{4}$ as opposed to two in $\mathbf{2}$. Cleavage of a metal-metal bond (Ru(1)-Ru(2) in 2) accompanies $\mathrm{CO}$ addition with the $\mathrm{Ru}(1) \cdots \mathrm{Ru}(2)$ distance in 4 (4.015(1) $\AA$ ) clearly indicating the absence of any bonding interaction. The $\mu-\mathrm{PPh}_{2}$ bridge across this open Ru... Ru vector subtends a $R u(1)-P(1)-R u(2)$ angle of 111.9$(1)^{\circ}$ and accounts for the high-field ${ }^{31} \mathrm{P}$ NMR shift. Perhaps the most unusual feature of $\mathbf{4}$ and the overall transformation of $\mathbf{2}$ to $\mathbf{4}$ is the insertion of $\mathrm{CO}$ into the $\mathrm{Ru}(1)-\mathrm{C}(10)$ (al kylidene) bond to generate new metal carbon $(\mathrm{Ru}(1)-\mathrm{C}(52)=2.143(9) \AA)$ and carbon-carbon $(C(10)-C(52)=1.52(1) \AA)$ bonds. Thus, the formally el ectronically and coordinatively unsaturated pendant ruthenium atom in cluster $\mathbf{2}$ achieves a full 18e count in $\mathbf{4}$, al beit separated from the remaining $\mathrm{Ru}_{3}$ cluster unit. The coordination geometry at $R u(1)$ in $\mathbf{4}$ is that

(8) Selected spectroscopic data for 4: IR (KBr) $v(\mathrm{CO}) 2145$ (m), 2103 (w), 2075 (s), 2053 (s), 2028 (m), 1992 (vs), 1971 (s), 1957 (m), 1946 (m), 1931 (m), $1918(\mathrm{w}), 1900(\mathrm{~m}), 1638(\mathrm{~m}), 1617(\mathrm{~s}) \mathrm{cm}^{-1} ;{ }_{1} \mathrm{H}$ NMR $\left(300 \mathrm{MHz} \mathrm{CDCl}_{3}\right) \delta 8.05-6.45(\mathrm{~m}, \mathrm{Ph}) ;{ }^{31} \mathrm{P}\left\{{ }^{1} \mathrm{H}\right\} \mathrm{NMR}(121.5 \mathrm{MHz}$, $\left.\mathrm{CDCl}_{3}\right) \delta 46.9$ (s, 1P), 26.7 (s, 1P). The facile loss of $\mathrm{CO}$ from 4 preduded satisfactory microanalysis. Crystal data for 4: $\mathrm{C}_{52} \mathrm{H}_{30} \mathrm{O}_{12} \mathrm{P}_{2} \mathrm{Ru}_{4} \cdot 0.88 \mathrm{CH}_{2-}$ $\mathrm{Cl}_{2}, \mathrm{M}_{\mathrm{r}}=1385.98$, monoclinic, space group $\mathrm{P} 2_{1} / \mathrm{n}, \mathrm{a}=14.2417(2) \AA$, b $=20.8937(5) \AA, c=17.9378(1) \AA, \beta=95.975(1)^{\circ}, V=5308.6(2) \AA^{3}, Z$ $=4, \rho_{\text {calc }}=1.734 \mathrm{~g} \mathrm{~cm}^{-3}, \mathrm{~F}(000)=2696.7, \lambda($ Mo K $\alpha)=0.70930 \AA$, T $=298 \mathrm{~K}, \mu=1.30 \mathrm{~mm}^{-1}$. The structure was solved and refined on the basis of 4339 (I $\geq 2.5 \sigma(\mathrm{I}))$ observed reflections (21910 measured) (Siemens SMART CCD diffractometer) using a crystal of dimensions $0.20 \times 0.20 \times 0.20 \mathrm{~mm}$. Final $R$ and $R_{w}$ values were 0.048 and 0.031 . A final difference map showed residual electron density from -0.67 to +0.87 e $\AA^{-3}$. A disordered solvent molecule was modeled as $\mathrm{CH}_{2} \mathrm{Cl}_{2}$, occupancy 0.88 , following trial refinement.

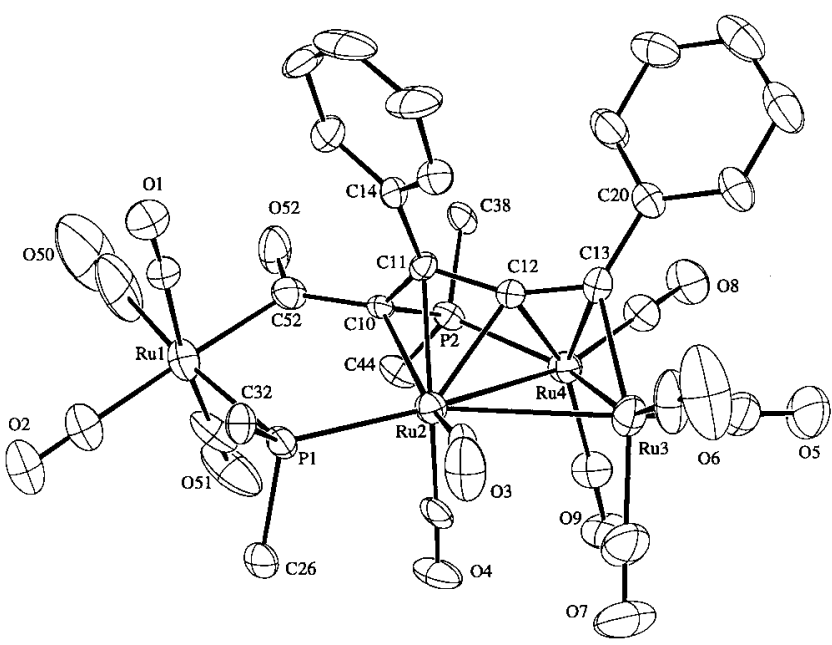

Figure 3. ORTEP plot of compound 4. Only the ipso carbons of the phenylphosphido groups are shown for darity. Selected bond lengths $(\AA)$ not given in thetext: Ru(1)-P(1), 2.437(3); Ru(2)-P(1), 2.406(2); Ru(2)-Ru(3), 3.037(1); $\mathrm{Ru}(2)-\mathrm{Ru}(4), 2.8352(9) ; \mathrm{Ru}(3)-\mathrm{Ru}(4), 2.669(1) ; \mathrm{P}(2)-$ $\mathrm{C}(10), 1.824(8) ; \mathrm{Ru}(4)-\mathrm{P}(2), 2.307(3) ; \mathrm{Ru}(2)-\mathrm{C}(10), 2.233(8) ;$ $\mathrm{C}(10)-\mathrm{C}(11), 1.46(1) ; \mathrm{C}(11)-\mathrm{C}(12), 1.42(1) ; \mathrm{C}(12)-\mathrm{C}(13)$, 1.36(1); Ru(2)-C(11), 2.191(8); Ru(2)-C(12), 2.151(8); Ru(3)-C(13), 2.083(9); Ru(4)-C(13), 2.293(9); Ru(4)-C(12), 2.096(8).

of a slightly distorted octahedron. While major changes have occurred at the unsaturated 16e site in $\mathbf{2}$, the remaining $\mathrm{Ru}_{3}$ fragment and associated ligands remain relatively unchanged, in keeping with the view that unsaturation in $\mathbf{2}$ is localized at a single site.

The sequence and mechanism of addition of three $\mathrm{CO}$ mol ecules to $\mathbf{2}$ is as yet unclear, since no intermediates could be detected by ${ }^{31 P}$ NMR spectroscopy. We note, however, that initial CO addition at Ru(1) in $\mathbf{2}$, followed by a second addition with $\mathrm{M}-\mathrm{M}$ bond cleavage, would afford a pseudooctahedral $\mathrm{Ru}(\mathrm{II})$ site from which $\mathrm{CO}$ insertion into the $\mathrm{Ru}(1)-\mathrm{C}(10)$ bond would be favored. ${ }^{9}$ However, while $\mathrm{CO}$ insertion into metal-alkyl and -aryl bonds is common, ${ }^{10}$ insertion into metal-alkylidenes is rare. ${ }^{11}$ We are currently investigating related additions to 2 .

Acknowledgment. This work was supported by grants from NSERC and NRC of Canada (to A.J .C.), the National Science Council of Taiwan (to Y.C. and S.M.P.), and the Comisión Interministerial de Ciencia y Tecnol ogía (Spain).

Supporting Information Available: Tables giving de tails of the X-ray structure determinations, atomic coordinates and anisotropic displacement parameters, bond lengths, and bond angles for $\mathbf{2}-\mathbf{4}$ (27 pages). Ordering information is given on any current masthead page.

\section{OM980168H}

(9) See for example: Barnard, C. F. J .; Daniels, J . A.; Mawby, R. J J. Chem. Soc., Dalton Trans. 1976, 961.

(10) Collman, J. P.; Hegedus, L. S.; Norton, J. R.; Finke, R. G. Principles and Applications of Organotransition Metal Chemistry, 2nd ed.; University Science Books: Mill Valley, CA, 1987.

(11) (a) Mott, G. N.: Granby, R., MacLaughlin, S. A.; Taylor, N. J Carty, A. J . Organometallics 1983, 2, 189. (b) Morrison, E. D.; Geoffroy, G. I. J . Am. Chem. Soc. 1985, 107, 3541.

(12) Gabe, E. J .; LePage, Y.; Charland, J .-P.; Lee, F. L.; White, P. S. J . Appl. Crystallogr. 1989, 22, 384. 